\title{
EVALUATION OF ANTIOXIDANT AND ANTIBACTERIAL ACTIVITIES OF VERNONIA AMYGDALINA LEAF EXTRACTS AS AN AUXILIARY IN NATURAL HAIR SHAMPOO
}

\author{
SIRIKHWAN TINRAT*, CHATCHAWAN SINGHAPOL \\ Department of Biotechnology, Faculty of Applied Science, King Mongkut's University of Technology North Bangkok, Bangkok, Thailand. \\ Email: sirikhwan.t@sci.kmutnb.ac.th
}

Received: 01 June 2020, Revised and Accepted: 14 July 2020

\section{ABSTRACT}

Objective: This study evaluated the phytochemical compounds, antioxidant, and antimicrobial activities of Vernonia amygdalina (VA) leaf extract and used it as an auxiliary herbal constituent in natural hair shampoo.

Methods: VA leaf was macerated in various solvents. All crude extracts were phytochemical compounds screened and determined the antioxidant and antimicrobial activities before formulating a natural shampoo formula. Natural shampoos were evaluated with physic-chemical properties and sensory satisfaction.

Results: About 95\% ethanolic extract was the most suitable substrate for product development. It reveals the inhibition zone from $7.00 \pm 0.00$ to $15.00 \pm 1.00 \mathrm{~mm}$ and possesses a broad spectrum of antibacterial agents against both Gram-positive and Gram-negative bacteria. The MICs and minimum bactericidal concentrations value ranged from 6.250 to $100 \mathrm{mg} / \mathrm{ml}$ and 25 to $>200 \mathrm{mg} / \mathrm{ml}$, respectively. About $95 \%$ ethanolic extract also revealed high antioxidant activity. The $\mathrm{IC}_{50}$ value of $\mathrm{DPPH}$ of $95 \%$ ethanolic extract was $1.88 \pm 0.02 \mu \mathrm{g} / \mathrm{ml}(\%$ inhibition of $85.73 \pm 0.01)$ and the ferric reducing ability power was $23.00 \pm 0.50 \mathrm{mg}$ AAE/100 gDW. These high biological activities may be due to a broad range of phytochemical compounds, including saponins, tannins, flavonoids, terpenoids, steroids, cardiac glycosides, and alkaloids.

Conclusions: The VA leaf was suitable to use as an ingredient in natural shampoos with a low detrimental effect on normal skin flora. The shampoo with $0.00188 \%$ of $95 \%$ ethanolic extract was the most suitable formula in terms of characteristics and stability. This formula also obtained the highest satisfaction level under our sensory evaluation.

Keywords: Vernonia amygdalina, Phytochemical compounds, Antioxidant and antimicrobial activities, Natural shampoo formulation.

(C) 2020 The Authors. Published by Innovare Academic Sciences Pvt Ltd. This is an open access article under the CC BY license (http://creativecommons. org/licenses/by/4. 0/) DOI: http://dx.doi.org/10.22159/ajpcr.2020.v13i10.38581

\section{INTRODUCTION}

Creating new natural products has presently received more attention due to their demand in the cosmeceutical industry. In Asia, topical herbal products containing bioactive ingredients with pharmacologic benefits have been used in creating beauty for thousands of years. However, there was little scientific literature to support the use of such ingredients in the modern cosmeceutical industry. Herbal plants have a natural-synthetic ability to produce bioactive compounds which called phytochemicals or secondary metabolites. These compounds exert bacteriostatic and bactericidal activities against pathogenic microorganisms. The continued research about the bioactivity of phytochemical compounds has the objective to discover novel biomolecules that possess to resist free radicals and pathogenic microorganisms for solving of the treatment failure (disease) [1]. The bioactive substances were not beneficial only in the medical field but also for pharmaceutical or cosmeceutical products. The shampoo is one of the important daily used requisites. The modern shampoo is generally made by combining surfactant, co-surfactant, soften, and conditional agent with the thickener and nourish agent [2]. However, new generation customers are consciously aware of the effects of overmuch synthetic chemical usage that may have a side effect such as hair loss, hair dryness and hair breakage. Therefore, products with natural ingredients received more attention due to their higher extra unique natural active compounds and lower side effects on the body.

Vernonia amygdalina (VA) (Nan Chao Wei), a member of the family Asteraceae, is a small shrubbery that grows throughout tropical Africa. It is called "bitter leaf" due to its bitter taste. Its leaf is served as the vegetable and culinary herb in soup [3]. This plant has presented various pharmacological properties such as antimicrobial [4], antifungal [5], antioxidant [6], anti-inflammatory [7], antitumor [8], anticancer [9], and anti-allergic [10]. Many bioactive compounds had been isolated from the extracts of VA such as flavonoids, saponins, terpenes, sesquiterpenes, edotides, xanthones, and alkaloids $[11,12]$. Therefore, this experiment will determine the phytochemical composition of VA leaf extracts growing in Thailand and specify the potential fraction that showed the ability of natural antioxidant and antimicrobial agents. The most suitable extracted will be used as an auxiliary compound in natural hair shampoo formulation and evaluated in terms of characteristics and stability. The satisfaction level and sensory evaluation will also be tested.

\section{METHODS}

Plant material and preparation of extracts

Fresh leaves of VA were collected from Min Buri District, Bangkok Province, Thailand, from Jan to May 2019. The leaves were properly cleaned with running tap water (2-3 times) and sterile distilled water (1 time), respectively. The plant materials were dried in shade and cut into small pieces in a size of $0.5-1.0 \mathrm{~cm}$. All leaf samples were then separately macerated with $95 \%$ ethanol, $75 \%$ acetone, and $99.8 \%$ chloroform solutions in a ratio of 1:20 (plant:solvent; [w/v]) for 7 days compared with boiled into distilled water (DW:ratio of 1:12.5; [w/v]) at $60^{\circ} \mathrm{C}$ for $30 \mathrm{~min}$. The mixture was filtered through a filter paper (Whatman No. 1) and centrifuged at $8000 \mathrm{rpm}$ for $15 \mathrm{~min}$. The filtrate obtained was subsequently concentrated under vacuum on a rotary evaporator. The concentrated crude extracts were kept at $-20^{\circ} \mathrm{C}$ under dark condition until further analysis. Approximately $0.1-0.2 \mathrm{mg} / \mathrm{ml}$ of crude extract solutions were prepared with each solvent extractions 
before further phytochemical screenings, total phenolic and flavonoid contents, and antioxidant activities study.

\section{Analysis of phytochemical constituents}

Qualitative screening of the phytochemical compounds of VA leaf extracts was carried out to evaluate the presence of chemical constituents including alkaloids, flavonoids, tannins, steroids, saponins, anthraquinones, cardiac glycosides, and terpenoids, according to the prescribed methods of Harborne (1998) [13].

\section{Estimation of total phenolic content (TPC)}

The quantitative of TPC was determined by Folin-Ciocalteu (FC) method according to the procedure of Singleton et al. (1999) [14] with slight modification. In brief, $100 \mu \mathrm{l}$ of extracted solution at an appropriate concentration $(0.2 \mathrm{mg} / \mathrm{ml})$ was thoroughly mixed with $750 \mu \mathrm{l}$ of fresh FC reagent (1:10 dilution with distilled water) and incubated at room temperature for $5 \mathrm{~min}$. Then, $750 \mu \mathrm{l}$ of $6 \%(\mathrm{w} / \mathrm{v})$ sodium carbonate $\left(\mathrm{Na}_{2} \mathrm{CO}_{3}\right)$ was added and allowed to completely react for $90 \mathrm{~min}$ under the dark condition at ambient temperature. The absorbance of the sample solution was measured at $725 \mathrm{~nm}$ by spectrophotometer (Hanon instruments, Japan). The standard curve in the range of 0.025$0.500 \mathrm{mg} / \mathrm{ml}$ of gallic acid was used for calculating the TPC. The result was expressed as $\mathrm{mg}$ of gallic acid equivalent per $100 \mathrm{~g}$ of dry weight (mg GAE/100 g DW).

\section{Estimation of total flavonoid content (TFC)}

TFC of crude extracts was analyzed using the aluminum chloride colorimetric assay according to the method described by Tinrat and Sila-asna (2017) [15]. In brief, $200 \mu \mathrm{l}$ of an appropriately diluted solution of the plant extracts $(0.2 \mathrm{mg} / \mathrm{ml})$ and $2.3 \mathrm{ml}$ of $30 \%$ methanol solution were mixed and followed by the addition of $100 \mu \mathrm{l}$ of $0.5 \mathrm{M}$ $\mathrm{NaNO}_{2}$ and $100 \mu \mathrm{l}$ of $0.3 \mathrm{M} \mathrm{AlCl}_{3}$, respectively. The resulting solution was thoroughly mixed with vortex and left to stand for 5 min in the dark at ambient temperature. The absorbance was taken against a reagent blank at $506 \mathrm{~nm}$ using UV spectrophotometer. The standard curve in the range of $0.25-5.00 \mathrm{mg} / \mathrm{ml}$ of rutin was used for calculating the TFC. The result was expressed as mg of rutin equivalent per $100 \mathrm{~g}$ of dry weight (mg RE/100 g DW).

\section{Antioxidant activities}

DPPH radical scavenging activity assay

Free radical scavenging activity of crude leaf extracts was evaluated according to the method of Jayalakshmia et al. (2015) [16] with slight modification. In brief, $100 \mu \mathrm{l}$ of sample extracts at an appropriate concentration $(0.2 \mathrm{mg} / \mathrm{ml})$ was mixed with $900 \mu \mathrm{l}$ of $0.1 \mathrm{mM} \mathrm{DPPH}$ in methanolic solution under vigorous shaking and incubated under dark condition. The absorbance value of solutions was read after $30 \mathrm{~min}$ incubation period at ambient temperature at $517 \mathrm{~nm}$. The antioxidant activity of the sample expressed as $\mathrm{IC}_{50}$ value was defined as concentration $(\mu \mathrm{g} / \mathrm{ml})$ of the sample that inhibits the DPPH radicals formation by $50 \%$. The $\mathrm{IC}_{50}$ values were calculated using linear regression graphs. The percentage of DPPH scavenging was calculated using the following formulation:

$$
\text { DPPH radical scavenging } \%=\left[\left(A_{0}-A_{1}\right) / A_{0}\right] \times 100
$$

Where $A_{0}$ is absorbance of the control (DPPH solution) $\mathrm{A}_{1}$ is an absorbance of the DPPH mixed with the sample.

\section{Ferric reducing antioxidant power assay (FRAP)}

The FRAP was proceeded as previously described by Benzie and Strain (1996) [17]. The freshly prepared FRAP reagent in acetate buffer $(1.6 \mathrm{~g}$ of sodium acetate and $8.0 \mathrm{ml}$ of acetic acid make up to $500 \mathrm{ml} ; \mathrm{pH} \mathrm{3.6)}$ was warmed to $37^{\circ} \mathrm{C}$ in the oven until used. A total of $300 \mu \mathrm{l}$ of tested extracts at an appropriate concentration $(0.2 \mathrm{mg} /$ $\mathrm{ml}$ ) and $2.7 \mathrm{ml}$ of the FRAP reagent was thoroughly mixed. After 30 min of incubation, the absorbance value of mixture solutions was read at $596 \mathrm{~nm}$. The standard curve in the range of $0.01-0.25 \mathrm{mg} / \mathrm{ml}$ of ascorbic acid was prepared. The results were expressed as $\mathrm{mg}$ of ascorbic acid equivalents/100 g dry weight (mg AAE/100g DW) of the plant materials.

\section{Determination of antimicrobial activity}

Microorganisms and culture condition

The antimicrobial effects of all crude extracts were determined against nine pathogenic strains, including the reference from the American Type Culture Collection and Laboratory collection strains (The Department of Biotechnology, King Mongkut's University of Technology North Bangkok, Thailand) as Bacillus cereus DMST 5040, Enterococcus faecalis DMST 4736, Staphylococcus aureus ATCC 25923, and Staphylococcus epidermidis for Gram-positive bacteria group and Escherichia coli ATCC 25922, Klebsiella pneumoniae, Pseudomonas aeruginosa ATCC 27853, Proteus mirabilis DMST 8212, and Salmonella typhimurium ATCC 13311 for Gram-Negative bacteria group. All tested microorganisms were maintained on brain heart infusion (BHI, Difco) agar medium under $37^{\circ} \mathrm{C}$.

\section{Preparation of plant extracts}

The stock solutions of plant extracts were dissolved in 5\% DMSO and sterile distilled water to a final concentration of $1000 \mathrm{mg} / \mathrm{ml}$ for agar diffusion assay and $400 \mathrm{mg} / \mathrm{ml}$ for broth microdilution methods (MIC values). The crude extract solutions at different concentrations of 50 , $100,200,300$, and $400 \mathrm{mg} / \mathrm{ml}$ were prepared before applying in agar disk diffusion assay.

\section{Agar disk diffusion assay}

In vitro antibacterial activity of crude extracts of VA leaf was carried out by agar disk diffusion method at the concentration 50, 100, 200, 300 , and $400 \mathrm{mg} / \mathrm{ml}$ against tested bacterial strains. In brief, overnight bacterial cultures of tested strains have adjusted the concentration of the $\left.1.0 \times 10^{8-9} \mathrm{CFU} / \mathrm{ml}^{\left(\mathrm{OD}_{600}\right.}=0.2\right)$ by spectrophotometer. The inoculums of tested microorganisms were transferred to solidified agar plates by sterile swab sticks and followed by the mounting of the impregnated sterile paper disk. After that, each paper disk was added with $10 \mu \mathrm{l}$ of each crude extract at different concentrations. Ampicillin (Amp, $10 \mu \mathrm{g} / \mathrm{ml}$ ) and ciprofloxacin (CIP, $10 \mu \mathrm{g} / \mathrm{ml}$ ) were used as a positive control. After 1-, 3-, and 5-day incubation at $37^{\circ} \mathrm{C}$, all plates were observed the zone of growth inhibition and the diameter of these zones was measured in millimeters ( $\mathrm{mm}$ ) [18].

Minimum inhibitory concentration (MIC) and minimum bactericidal concentration (MBC) assay

The MIC values of the extracts were carried out by a two-fold serial dilution method in 96 well microtiter to determine the susceptibilities of pathogenic strains and extracts [19]. The concentration of crude extracts range from 200 to $0.195 \mathrm{mg} / \mathrm{ml}$ was used. $200 \mu \mathrm{l}$ of plant extracts $(400 \mathrm{mg} / \mathrm{ml}$ of concentration) was added to each 96-well microplate well which contained $200 \mu \mathrm{l}$ of BHI broth. Then, $5 \mu \mathrm{l}$ of bacterial suspension with the concentration of $10^{8-9} \mathrm{CFU} / \mathrm{ml}\left(\mathrm{OD}_{600}=0.2\right)$ was added to each well. The 96-well microtiter plates were incubated at $37^{\circ} \mathrm{C}$ for $24 \mathrm{~h}$. Similar tests were performed simultaneously for growth controls (BHI + inoculums) and sterility controls (BHI + test sample). The first wells showing no visible disorder were considered as MIC values. Then, a small medium from MICs determination was transferred to the agar plates and re-culture to evaluate the MBC values.

\section{Development of natural hair shampoo}

Formulations of natural shampoos were prepared using different proportions (\%) of ingredients and concentration of VA leaf extracts (Table 1). The ingredient phases were prepared and mixed until an ideal homogeneous dispersion. The mixture was then mixed using slow stirring on a magnetic stirrer until no precipitate remained at the bottom.

\section{Physical appearance/visual inspection}

Five grams of each formulated shampoo were investigated for the physical appearance by organoleptic inspections in terms of external appearance, color, and odor [20] 
Table 1: Ingredients of natural shampoo formulations in this study

\begin{tabular}{|c|c|c|c|c|}
\hline \multirow[t]{2}{*}{ Ingredients } & \multirow[t]{2}{*}{ Function } & \multicolumn{3}{|c|}{ Formulation $(\% \mathrm{w} / \mathrm{w})$} \\
\hline & & A & B & C \\
\hline \multicolumn{5}{|l|}{ Phase A } \\
\hline Coco-glucoside and Glyceryl oleate (Lamesoft PO 65) & Soften and conditional agent & 3.65 & 3.65 & 3.65 \\
\hline Coconut Diethanoiamide Glycerine (Aminon C-025) & Thickener/Viscosity adjuster & 2.95 & 2.95 & 2.95 \\
\hline Cocamidopropyl betaine (CAPB) & Surfactant/Cleaning Agent & 2.95 & 2.95 & 2.95 \\
\hline \multicolumn{5}{|l|}{ Phase B } \\
\hline Deionized Water & Diluent & 72.8 & 68.799 & 68.782 \\
\hline Polyquaternium - 7 (PQ 7) & Conditioning agent & 2.45 & 2.45 & 2.45 \\
\hline Sodium lauryl sulfate (EMAL 10G) & Surfactant (Anionic) & 2.45 & 2.45 & 2.45 \\
\hline \multicolumn{5}{|l|}{ Phase $\mathrm{C}$} \\
\hline Vitamin B5 & Nourish hair & - & 1.00 & 1.00 \\
\hline Keratin & Nourish hair & - & 1.00 & 1.00 \\
\hline \multicolumn{5}{|l|}{ Phase D } \\
\hline Vernonia amygdalina (bitter leaf) extracts & Active ingredient & - & 0.00188 & 0.0188 \\
\hline \multicolumn{5}{|l|}{ Phase E } \\
\hline Fragrance & Fragrance & - & 2.00 & 2.00 \\
\hline Total & & 100 & 100 & 100 \\
\hline
\end{tabular}

\section{Determination of wetting time}

The wetting time of the formulated shampoo was determined. Oneinch square paper was placed on the aqueous solution of $1 \%(w / w)$ shampoo. The time has been recorded until a paper was becoming wet [21].

\section{Dirt dispersion}

Two drops of formulated shampoos were added to $10 \mathrm{ml}$ of distilled water in the tested tube. One drop of India ink was added, then stops and shakes for 10 times [22]

\section{Sensory evaluation of formulated natural shampoo}

All formulated shampoos were evaluated the sensory, including the appearance, odor, color, foaming quantity, feelings after use, packaging, and overall acceptability by 5 -point hedonic scales compared with a commercialize shampoos ( 5 = like extremely to 1 = dislike extremely; 30 persons)

\section{Determination of solid content (\%)}

The solid content of the formulated shampoos was investigated. In brief, $4 \mathrm{~g}$ of the sample was placed in an evaporating dish for a total weight recorded. The evaporating dish was placed in a water bath to dryness. After complete evaporation, the evaporating dish was weighed again after cooling down to room temperature. The percentage of solid content was then calculated after the sample was completely dry.

\section{pH measurement}

The formula shampoos were diluted in distilled water to achieve the final concentration of $10 \%(\mathrm{v} / \mathrm{v})$. The $\mathrm{pH}$ was measured using a $\mathrm{pH}$ meter at room temperature [22].

\section{Foaming ability and foam stability}

Foaming ability was determined by the cylinder shake method with slight modification. Fifty milliliters of the 1\% shampoo solution were put into a $250 \mathrm{ml}$ graduated cylinder. The cylinder was covered and shakes. The total volume of the foam content every 1 min was recorded and continuously done until $5 \mathrm{~min}$ [22].

\section{Statistical analysis}

Results were performed in triplicate and expressed as mean \pm SD. Significance differences for multiple comparisons were assessed by the one-way ANOVA and followed by t-tests. Statistical significance was taken at $95 \%$ confidence $(\mathrm{p} \leq 0.05)$.

\section{RESULTS AND DISCUSSION}

\section{Phytochemical screening}

The percent yield of VA crude extraction was ranged from 7.5\% to $30 \%$ as in distilled water extract (DWE; 30.00\%), 95\% ethanol (EE; 22.50\% $[\mathrm{w} / \mathrm{v}]$ ), $99.8 \%$ chloroform (CE; $17.50 \%[\mathrm{w} / \mathrm{v}]$ ), and $75 \%$ acetone extract (AE; $7.50 \%[\mathrm{w} / \mathrm{v}])$. The difference in yield percentage was depended on the influence of different polarities of solvent solutions. The qualitative phytochemical screening of VA leaf extract in different solvents was showed in Table 2. The crude extracts of VA leaf revealed some secondary metabolites, including saponins, tannin, flavonoids, steroids, terpenoids, and alkaloids. In this experiment, acetone extracts (AE) of VA leaf represented the highest amount of the phytoconstituents, including saponins, tannin, steroids, terpenoids, cardiac glycosides, and alkaloids. Steroids and terpenoids which were major phytochemical components of VA leaf were found in all solvent.

From all extractions, seven phytochemical compounds were found in VA leaf extracts, whereas anthraquinones have not been found in any solvent in this experiment. Saponins, steroids, terpenoids, and cardiac glycosides were found in three solvent extracts (aqueous, 95\% ethanol, and $75 \%$ acetone) which was consistent with the study of Alara et al. (2019) [4]. These seven phytochemical compounds found can exert antimicrobial and antioxidant activities [23-25]. In the previous studies of VA, different main constituents have been reported, including flavonoids [26], saponins [27], terpenoids [26, 27], anthraquinones [27], and alkaloids [27], steroids [27], tannins [26], and cardiac glycosides [27]. This experiment has found the different amounts and components of phytochemical compound compare with the previous studies. The reason of this difference might be because of the difference in plantation area, whether condition, water level, and soil condition, for example. Different plantation conditions might influence the appearance of phytochemical composition in VA.

Quantitative analysis of the total phenolic and flavonoid contents Phenolic and flavonoids are plant secondary metabolites that possess several pharmacological activities, including antioxidant, anti-inflammatory, antimicrobial, anticancer, and among biological activities [28]. In this experiment, all VA leaf extracts for each solvent were assayed for total phenolic and flavonoid content (TPC and TFC). Quantitative analysis of TPC and TFC is shown in Table 3. The highest TPC was significantly obtained for aqueous extract (DWE) followed by $75 \%$ acetonic and $95 \%$ ethanolic extracts as $374.10 \pm 1.40,69.30 \pm 0.70$, and $772.80 \pm 0.7 \mathrm{mg} \mathrm{GAE} / 100 \mathrm{~g} \mathrm{FW}(\mathrm{p} \leq 0.05)$, respectively. The TFC of VA leaf extracts were range from $69.30 \pm 0.70$ to $772.8 \pm 0.70 \mathrm{mg} \mathrm{RE} / 100 \mathrm{~g}$ FW. The $75 \%$ acetonic extract with $772.8 \pm 0.70 \mathrm{mg}$ RE/100 g FW of TFC showed 
Table 2: Preliminary phytochemical analysis of Vernonia amygdalina (bitter leaf) extracts

\begin{tabular}{|c|c|c|c|c|}
\hline Phytochemical compounds & Distilled water & 95\% Ethanol & 75\% Acetone & 99.8\% Chloroform \\
\hline \multicolumn{5}{|l|}{ Saponin } \\
\hline Froth test & ++ & + & + & - \\
\hline \multicolumn{5}{|l|}{ Tannin } \\
\hline $10 \% \mathrm{FeCl}_{3}$ & - & - & +++ & - \\
\hline \multicolumn{5}{|l|}{ Flavonoid } \\
\hline Shinoda test & - & + & - & + \\
\hline $10 \%$ lead (IV) acetate & + & - & - & - \\
\hline \multicolumn{5}{|l|}{ Steroid } \\
\hline Liebermann test & - & + & + & ++ \\
\hline Keller-Kiliani test & +++ & + & + & + \\
\hline \multicolumn{5}{|l|}{ Terpenoid } \\
\hline Salkowski test & + & ++ & ++++ & +++ \\
\hline \multicolumn{5}{|l|}{ Cardiac glycosides } \\
\hline Kedde reagent & - & - & +++ & + \\
\hline Keller-Kiliani Test $+10 \% \mathrm{FeCl}_{3}$ test & - & - & - & + \\
\hline \multicolumn{5}{|l|}{ Alkaloid } \\
\hline Dragendorff's reagent & - & - & +++ & ++ \\
\hline $28 \% \mathrm{NH}_{4} \mathrm{OH}$ & - & - & - & - \\
\hline Wagner's reagent & - & - & +++ & ++ \\
\hline
\end{tabular}

+: Presence, -: Absence

Table 3: Total phenolic and flavonoid contents and antioxidant activities of $\mathrm{V}$. amygdalina leaf extracts

\begin{tabular}{|c|c|c|c|c|}
\hline \multirow[t]{2}{*}{ Tests } & \multicolumn{4}{|c|}{ Solvent extraction } \\
\hline & Distilled water & 95\% Ethanol & 75\% Acetone & 99.8\% Chloroform \\
\hline Total phenolic content (mg GAE/100g FW; \pm SD) & $374.10 \pm 1.40^{*}$ & $158.50 \pm 0.50$ & $315.7 \pm 1.40$ & $88.2 \pm 1.40$ \\
\hline Total flavonoids content (mg RE/100g DW; \pm SD) & $69.30 \pm 0.70$ & $77.00 \pm 0.50$ & $772.8 \pm 0.70^{*}$ & $258.30 \pm 0.70$ \\
\hline \multicolumn{5}{|l|}{ Antioxidant capacity } \\
\hline FRAP assay (mg AAE/100 g DW; \pm SD) & $179.20 \pm 0.70$ & $23.00 \pm 0.50$ & $448.00 \pm 2.80^{*}$ & $112.00 \pm 0.70$ \\
\hline DPPH assay (mg AAE/100g DW \pm SD) & $160.30 \pm 0.50$ & $283.50 \pm 0.50^{*}$ & $173.60 \pm 0.70$ & $217.00 \pm 0.70$ \\
\hline $\mathrm{IC}_{50 \text { Sample }} ; \mu \mathrm{g} / \mathrm{ml}$ & $16.40 \pm 0.03$ & $1.88 \pm 0.02^{*}$ & $8.32 \pm 0.04$ & $3.52 \pm 0.04$ \\
\hline $\mathrm{IC}_{50 \text { Ascorbic acid }} ; \mu \mathrm{g} / \mathrm{ml}$ & $0.166 \pm 0.001$ & & & \\
\hline
\end{tabular}

GAE: Gallic acid equivalent, RE: Rutin equivalent, AAE: Ascorbic acid equivalent, IC50 : 50\% Inhibitory concentration, ${ }^{*}$ : $\leq 0.05$, Ascorbic: Standard control

significantly higher antioxidant activity $(\mathrm{p} \leq 0.05)$ compare with other extracts (Table 3). However, fraction with higher phenolic and flavonoid contents had not always been represented strong antioxidant activity. The different solvent type has a significant influence on quantitative analysis and the concentration of phenolic and flavonoid compounds but not the antioxidant activity.

\section{Antioxidant activities of VA leaf extracts}

Oxidative stress is an imbalance of free radicals and antioxidant agents in the body. It has been reported to be associated with various human diseases and aging [29]. In this study, VA leaf extracts expressed an in vitro antioxidant activity when examined with DPPH radical scavenging assay and radical scavenging properties (FRAP assay) as $\mathrm{IC}_{50}$ in Table 3.

DPPH free radical is widely used to determine the radical scavenging activity of natural substances because of its stability. The radical scavenging activity in the presence of a hydrogen donating antioxidant can be monitored by reducing the adsorption of DPPH solution. $\mathrm{IC}_{50}$ is the concentration of the samples required to inhibit $50 \%$ of free radical. Thus, lower in $\mathrm{IC}_{50}$ indicates the higher of antioxidant activity. The $95 \%$ ethanolic extract of VA leaf showed highest scavenging activity of DPPH radical $\left(\mathrm{IC}_{50}=1.88 \pm 0.02 \mu \mathrm{g} / \mathrm{ml}\right.$; \% inhibition $=85.73 \pm 0.01$ ) that indicates approximately eight, four, and two-fold higher antiradical activity when compared with aqueous $\left(\mathrm{IC}_{50}=16.40 \pm 0.03 \mu \mathrm{g} / \mathrm{ml}\right), 75 \%$ acetone $(8.32 \pm 0.04 \mu \mathrm{g} / \mathrm{ml})$ and $99.8 \%$ chloroform $(3.52 \pm 0.04 \mu \mathrm{g} / \mathrm{ml})$ extracts, respectively (Table 3 ). The $\mathrm{IC}_{50}$ values of the standard ascorbic acid were $0.166 \pm 0.001 \mu \mathrm{g} / \mathrm{ml}$. The antioxidant activity of VA leaf was accordingly estimated by FRAP assay, which is presenting of the sample reduction of Fe (III) /tripyridyltriazine (TPTZ) complex to the ferrous form (blue color) (Table 3). In this study, the 75\% acetonic extract of VA leaf showed the highest amount of ferric reducing power expressed as ascorbic acid (448.00 $\pm 2.80 \mathrm{AAE} / 100 \mathrm{~g} \mathrm{DW})$ followed by aqueous extracts $(179.20 \pm 0.70 \mathrm{mg} \mathrm{AAE} / 100 \mathrm{~g} \mathrm{DW})$. There was no correlation between antioxidant activity by DPPH assay and total phenolic and flavonoid content among the various crude extracts. In spite of the lower phenolics and flavonoids content, $95 \%$ ethanolic extract showed higher antioxidant activity by DPPH assay (\% Inhibition and $\mathrm{IC}_{50}$ ), but not in FRAP assay. In the other hand, 75\% acetonic extract showed the highest total phenolic and flavonoid content and ferric reducing antioxidant (FRAP) assay, but it was not a correlation with DPPH free radical scavenging assay. These results clearly show that the amounts of phenolic and flavonoid in the crude VA leaf extracts are not an indicator for antioxidant power. However, different antioxidant power might be due to other secondary metabolites contained in this plant extracts such as phytol $(56.30 \%)[4,6]$ which was found to present a strong antioxidant, anti-microbial, anti-inflammatory, and anti-proliferative activity. This phytol was also found to be cytotoxic against breast cancer cell lines MCF7 [30]. Furthermore, synergistic or antagonistic effects among the different phytochemical are also possible in terms of antioxidant. The antioxidant capacities of the crude extracts have a strong relationship with the solvent employed, mainly due to the different antioxidant potential of compounds with different polarities [31].

\section{Antimicrobial activity}

The antibacterial activity of aqueous, 95\% ethanol, 75\% acetone, and $998 \%$ chloroform extracts of VA leaf was investigated against nine pathogenic strains using by agar disk diffusion method. The 
Table 4: Antibacterial activities of V. amygdalina leaf extracts against some bacterial pathogens

\begin{tabular}{|c|c|c|c|c|c|c|c|c|c|}
\hline \multirow[t]{3}{*}{ Concentration $(\mathrm{mg} / \mathrm{ml})$} & \multicolumn{9}{|c|}{ Zone of growth inhibition $(\varnothing=6 \mathrm{~mm}) ; \mathrm{mm} \pm S D$} \\
\hline & \multicolumn{4}{|c|}{ Gram-positive strains } & \multicolumn{5}{|c|}{ Gram-negative strains } \\
\hline & BC & EF & SA & SE & EC & KP & PA & PM & ST \\
\hline \multicolumn{10}{|l|}{ Distilled water } \\
\hline 50 & $\mathrm{R}$ & $\mathrm{R}$ & $\mathrm{R}$ & $\mathrm{R}$ & $\mathrm{R}$ & $\mathrm{R}$ & $8.33 \pm 0.58^{\mathrm{h}}$ & $9.00 \pm 1.00^{\mathrm{gh}}$ & $\mathrm{R}$ \\
\hline 100 & $\mathrm{R}$ & $\mathrm{R}$ & $\mathrm{R}$ & $\mathrm{R}$ & $\mathrm{R}$ & $\mathrm{R}$ & $7.67 \pm 0.58^{i j}$ & $7.00 \pm 0.00^{j}$ & $\mathrm{R}$ \\
\hline 200 & $\mathrm{R}$ & $\mathrm{R}$ & $\mathrm{R}$ & $\mathrm{R}$ & $7.00 \pm 0.00^{j}$ & $\mathrm{R}$ & $7.00 \pm 0.00^{j}$ & $8.00 \pm 1.00^{\mathrm{hi}}$ & $\mathrm{R}$ \\
\hline 300 & $7.00 \pm 0.00^{j}$ & $\mathrm{R}$ & $\mathrm{R}$ & $\mathrm{R}$ & $12.00 \pm 1.00^{\text {de }}$ & $9.33 \pm 0.58^{g}$ & $8.67 \pm 0.58^{\mathrm{h}}$ & $9.00 \pm 1.00^{\mathrm{gh}}$ & $\mathrm{R}$ \\
\hline 400 & $7.00 \pm 0.00^{j}$ & $\mathrm{R}$ & $\mathrm{R}$ & $\mathrm{R}$ & $12.33 \pm 0.58^{\mathrm{d}}$ & $11.33 \pm 0.58^{\mathrm{e}}$ & $8.00 \pm 0.00^{\mathrm{hi}}$ & $8.67 \pm 0.58^{\mathrm{h}}$ & $\mathrm{R}$ \\
\hline \multicolumn{10}{|l|}{ 95\% Ethanol } \\
\hline 50 & $7.00 \pm 0.00^{j}$ & $\mathrm{R}$ & $\mathrm{R}$ & $\mathrm{R}$ & $\mathrm{R}$ & $7.00 \pm 0.00^{j}$ & $7.00 \pm 0.00^{\mathrm{j}}$ & $9.67 \pm 0.58^{g}$ & $\mathrm{R}$ \\
\hline 100 & $8.33 \pm 0.58^{\mathrm{h}}$ & $\mathrm{R}$ & $8.67 \pm 0.58^{\mathrm{h}}$ & $\mathrm{R}$ & $\mathrm{R}$ & $7.00 \pm 0.00^{j}$ & $7.00 \pm 0.00^{j}$ & $10.67 \pm 0.58^{\mathrm{f}}$ & $\mathrm{R}$ \\
\hline 200 & $15.00 \pm 1.00^{\mathrm{b}}$ & $7.00 \pm 0.00^{j}$ & $\mathrm{R}$ & $\mathrm{R}$ & $\mathrm{R}$ & & $7.00 \pm 0.00^{j}$ & $10.00 \pm 0.00$ & $\mathrm{R}$ \\
\hline 300 & $12.00 \pm 1.00^{\mathrm{de}}$ & $\mathrm{R}$ & $7.00 \pm 0.58^{j}$ & $\mathrm{R}$ & $7.00 \pm 0.00^{j}$ & $8.33 \pm 0.58^{\mathrm{h}}$ & $8.00 \pm 0.00^{\mathrm{hi}}$ & $9.00 \pm 0.00^{\mathrm{gh}}$ & $\mathrm{R}$ \\
\hline 400 & $11.67 \pm 0.58^{\mathrm{e}}$ & $\mathrm{R}$ & $\mathrm{R}$ & $\mathrm{R}$ & $\mathrm{R}$ & $7.00 \pm 0.00^{j}$ & $7.00 \pm 0.00^{\mathrm{j}}$ & $7.00 \pm 0.00^{\mathrm{j}}$ & $\mathrm{R}$ \\
\hline \multicolumn{10}{|l|}{ 75\% Acetone } \\
\hline 50 & $7.00 \pm 0.00^{j}$ & $\mathrm{R}$ & $12.67 \pm 0.58^{\mathrm{d}}$ & $\mathrm{R}$ & $7.00 \pm 0.00^{j}$ & $\mathrm{R}$ & $7.00 \pm 0.00^{j}$ & $\mathrm{R}$ & $\mathrm{R}$ \\
\hline 100 & $10.33 \pm 0.58^{\mathrm{f}}$ & $\mathrm{R}$ & $12.33 \pm 0.58^{\mathrm{d}}$ & $\mathrm{R}$ & $7.00 \pm 0.00^{j}$ & $\mathrm{R}$ & $7.00 \pm 0.00^{j}$ & $\mathrm{R}$ & $\mathrm{R}$ \\
\hline 200 & $10.67 \pm 0.58^{\mathrm{f}}$ & $\mathrm{R}$ & $15.00 \pm 1.00^{\mathrm{b}}$ & $\mathrm{R}$ & $7.00 \pm 0.00^{j}$ & $9.33 \pm 0.58^{g}$ & $9.00 \pm 0.00^{\mathrm{gh}}$ & $7.00 \pm 0.00^{\mathrm{j}}$ & $\mathrm{R}$ \\
\hline 300 & $11.67 \pm 0.58^{\mathrm{e}}$ & $7.00 \pm 0.00^{j}$ & $16.00 \pm 1.00^{\mathrm{a}}$ & $7.00 \pm 0.00^{j}$ & $7.00 \pm 0.00^{j}$ & $9.67 \pm 0.58^{g}$ & $8.33 \pm 0.58^{\mathrm{h}}$ & $\mathrm{R}$ & $\mathrm{R}$ \\
\hline 400 & $12.33 \pm 0.58^{\mathrm{d}}$ & $8.00 \pm 0.00^{\text {hi }}$ & $16.33 \pm 0.58^{\mathrm{a}}$ & $\mathrm{R}$ & $7.00 \pm 0.00^{j}$ & $9.33 \pm 0.58^{\mathrm{g}}$ & $9.33 \pm 0.58^{g}$ & $7.00 \pm 0.00^{j}$ & $\mathrm{R}$ \\
\hline \multicolumn{10}{|l|}{ 99.8\% Chloroform } \\
\hline 50 & $7.00 \pm 0.00^{j}$ & $\mathrm{R}$ & $11.33 \pm 0.58^{\mathrm{e}}$ & $10.67 \pm 0.58^{\mathrm{f}}$ & $\mathrm{R}$ & $\mathrm{R}$ & $7.00 \pm 0.00^{\mathrm{j}}$ & $7.00 \pm 0.00^{j}$ & $\mathrm{R}$ \\
\hline 100 & $7.00 \pm 0.00^{j}$ & $\mathrm{R}$ & $10.00 \pm 1.00^{\mathrm{fg}}$ & $8.33 \pm 0.58^{\mathrm{h}}$ & $7.67 \pm 0.58^{\mathrm{i}}$ & $\mathrm{R}$ & $7.00 \pm 0.00^{j}$ & $7.00 \pm 0.00^{j}$ & $\mathrm{R}$ \\
\hline 200 & $11.67 \pm 0.58^{\mathrm{e}}$ & $\mathrm{R}$ & $8.67 \pm 0.58^{\mathrm{h}}$ & $8.00 \pm 0.00^{\mathrm{hi}}$ & $\mathrm{R}$ & $\mathrm{R}$ & $8.00 \pm 0.00^{\text {hi }}$ & $\mathrm{R}$ & $\mathrm{R}$ \\
\hline 300 & $12.00 \pm 0.00^{\text {de }}$ & $7.00 \pm 0.00^{j}$ & $11.33 \pm 0.58^{\mathrm{e}}$ & $8.00 \pm 0.00^{\mathrm{hi}}$ & $\mathrm{R}$ & $\mathrm{R}$ & $7.33 \pm 0.58^{i j}$ & $\mathrm{R}$ & $\mathrm{R}$ \\
\hline 400 & $12.33 \pm 0.58^{\mathrm{d}}$ & $7.00 \pm 0.00^{j}$ & $13.67 \pm 0.58^{c}$ & $9.00 \pm 0.00^{\mathrm{gh}}$ & $7.00 \pm 0.00^{j}$ & $\mathrm{R}$ & $7.00 \pm 0.00^{j}$ & $\mathrm{R}$ & $\mathrm{R}$ \\
\hline
\end{tabular}

abcdefghij is significant at the 0.05 level (p<0.05). BC: B. cereus DMST 5040, EF: E. faecalis DMST 4736, SA: S. aureus ATCC 25923, SE: S. epidermidis, EC: E. coli ATCC 25922, KP: K. pneumoniae, PA: P. aeruginosa ATCC 27853, PM: P. mirabilis DMST 8212, and ST: S. typhimurium ATCC 13311, R: Resistance

antibacterial activity was measured in terms of a diameter of the inhibition zone shown in Table 4. The antibacterial activity of crude VA leaf extracts was depending on the solvent nature used for extraction and the concentration of the plant extract. The $95 \%$ acetonic extract was presenting more antibacterial activities when compared with the aqueous, $95 \%$ ethanol and $99.8 \%$ chloroform extract. This result attributed to the previous results that acetonic extract contains more of the bioactive component when compared with other solvent extracts. Gram-positive strains, including B. cereus DMST 5040 $(7.00 \pm 0.00-15.00 \pm 1.00 \mathrm{~mm})$ and S. aureus ATCC $245923(7.00 \pm 0.00-$ $16.33 \pm 0.58 \mathrm{~mm}$ ) and Gram-negative strains, including P. aeruginosa ATCC $27853(7.00 \pm 0.00-9.33 \pm 0.58 \mathrm{~mm})$ and P. mirabilis DMST 8212 $(7.00 \pm 0.00-10.67 \pm 0.58)$ were more sensitive to all crude extracts while $S$. typhimurium ATCC 13311 was the most resistance to all concentrations of crude extracts and showing no inhibition zones.

In this study, the aqueous extract was not found to inhibit all gram-positive pathogens and three Gram-negative pathogens (E. coli ATCC 25922, K. pneumoniae, and S. typhimurium ATCC 13311). The acetonic and ethanolic extracts of VA leaf showed potential activity against seven out of nine tested organisms with the inhibition zone ranged between $7.00 \pm 0.00-16.33 \pm 0.58$ $\mathrm{mm}$ and $7.00 \pm 0.00-15.00 \pm 1.00 \mathrm{~mm}$, respectively. All crude extracts displayed weak antibacterial activity against Gram-positive bacterial, especially aqueous extracts (IZ=7.00 $\pm 0.00 \mathrm{~mm}$ ). The $99.8 \%$ chloroform displayed weak antibacterial activity against Gram-negative bacterial (IZ=7.00 $\pm 0.00-8.00 \pm 0.00 \mathrm{~mm})$. The zone of inhibition of ampicillin control $(10 \mu \mathrm{g})$ and CIP control $(10 \mu \mathrm{g})$ ranges from $7.00 \pm 0.00-41.33 \pm 0.58 \mathrm{~mm}$ to $7.00 \pm 0.00-37.67 \pm 0.58 \mathrm{~mm}$, respectively (Data not shown).

The result of this study was consistent with Arekemase et al. (2013) [32]. They found that the ethanolic extract of VA leaf showed effective resistance against E. coli, S. aureus, P. aeruginosa, and K. pneumoniae. This result also correlated to the results of Lyumugabe et al. (2017) [33] that the crude leaf extract of VA can resist against E. coli, S. aureus, and S. typhimurium. On the other hand, this finding contradicts the result of Ogundare (2011) [34] which found no antimicrobial properties of ethanolic extract of VA leaf against $E$. coli and $P$. aeruginosa.
The in vitro the antibacterial activity of crude VA leaf extracts in broth micro-dilution has been shown in Table 5. The MIC analysis of VA leaf extracts showed the optimum bacteriostatic concentration for aqueous, acetone, and chloroform extracts, while MBC analysis of ethanolic extract represented the optimum bactericidal concentration in all tested bacterial strains. The MIC value of aqueous, $95 \%$ ethanol, and $75 \%$ acetone crude extracts against all tested pathogenic bacterial showed the interval from 25 to $200 \mathrm{mg} / \mathrm{ml}$. Most of the Gram-positive bacteria tested in this experiment were more susceptible to all extracts than Gramnegative, especially Bacillus cereus DMST 5040 (MIC $=25-100 \mathrm{mg} / \mathrm{ml}$ and $\mathrm{MBC}=50->200 \mathrm{mg} / \mathrm{ml})$. E. coli ATCC 25922 showed more resistant to all crude extracts (MIC $=100->200 \mathrm{mg} / \mathrm{ml}$ and $\mathrm{MBC}=200-$ $>200 \mathrm{mg} / \mathrm{ml}$ ). The $95 \%$ ethanolic extract of VA leaf showed the strongest inhibitory activity against all bacterial strains growth, followed by $75 \%$ acetone, 99.8\% chloroform, and distilled water (aqueous), respectively. All tested bacterial strains were susceptible to ampicillin and CIP. In the study of Habtom and Gebrehiwo (2019) [35], the MIC values of ethanolic extract of VA leaf against $S$. aureus and E. coli were 25 and $100 \mathrm{mg} / \mathrm{ml}$ that was similar with this study. However, our result was controversy to the findings of Evbuomwan et al. (2018) [27] which showed the MICs of $S$. aureus and E. coli equal to 100 and $25 \mathrm{mg} / \mathrm{ml}$, respectively.

Based on our antimicrobial activity, the crude extracts of VA leaf showed inhibitory activity against all nine pathogenic strain, including Gram-positive and Gram-negative strains which indicate their broadspectrum activity. The difference in antimicrobial effects of VA leaf with the previous studies may due to the age of the plant used, freshness of plant materials, physical factors for growth (light and water), and microbial contamination in the field [36]. The difference sensitivity in susceptibility between Gram-positive and -negative strains to various crude extracts could be due to the structural difference in the bacterial cell wall, composition of outer membrane, and the amount of peptidoglycan. Gram-positive cell wall contains high peptidoglycan content with teichoic acids and showed a thicker cell wall than the Gram-negative cell wall which has a thin peptidoglycan layer without teichoic acids [37]. 
Table 5: The MICs and MBCs of V. amygdalina leaf extracts against some pathogenic strains by broth microdilution method

\begin{tabular}{|c|c|c|c|c|c|c|c|c|c|}
\hline \multirow[t]{3}{*}{ Solvents extraction } & \multicolumn{9}{|c|}{ Microorganisms } \\
\hline & \multicolumn{4}{|c|}{ Gram-positive strains } & \multicolumn{5}{|c|}{ Gram-negative strains } \\
\hline & $\mathrm{BC}$ & EF & SA & SE & EC & KP & PA & PM & ST \\
\hline \multicolumn{10}{|l|}{ Distilled water } \\
\hline MIC & 100 & 100 & 100 & 200 & 200 & 100 & 100 & 200 & 200 \\
\hline MBC & $>200$ & $>200$ & $>200$ & $>200$ & $>200$ & $>200$ & $>200$ & $>200$ & $>200$ \\
\hline \multicolumn{10}{|l|}{ 95\% Ethanol } \\
\hline MIC & 25 & 25 & 25 & 100 & 100 & 50 & 50 & 100 & 50 \\
\hline MBC & 50 & 100 & 100 & 200 & 200 & 200 & 200 & 200 & 200 \\
\hline \multicolumn{10}{|l|}{ 75\% Acetone } \\
\hline MIC & 50 & 100 & 6.25 & 200 & 200 & 100 & 100 & 200 & 200 \\
\hline MBC & 50 & 100 & 25 & 200 & $>200$ & 100 & 100 & 200 & $>200$ \\
\hline \multicolumn{10}{|l|}{ 99.8\% Chloroform } \\
\hline MIC & 100 & 100 & 50 & 200 & 200 & 50 & 200 & 100 & $>200$ \\
\hline MBC & 200 & $>200$ & 200 & $>200$ & $>200$ & 200 & $>200$ & $>200$ & $>200$ \\
\hline \multicolumn{10}{|l|}{ Antibiotics } \\
\hline \multicolumn{10}{|l|}{ Ampicil-lin } \\
\hline MIC & 0.039 & 0.009 & 0.156 & 0.019 & 0.156 & 0.009 & 0.019 & 0.019 & 0.078 \\
\hline MBC & 0.039 & 0.009 & 0.156 & 0.019 & 0.156 & 0.009 & 0.019 & 0.039 & 0.078 \\
\hline \multicolumn{10}{|l|}{ Cipro-floxacin } \\
\hline MIC & 0.156 & 0.313 & 0.019 & 0.002 & 0.019 & 0.313 & 0.009 & 0.004 & 0.078 \\
\hline MBC & 0.156 & 0.625 & 0.039 & 0.002 & 0.019 & 0.625 & 0.019 & 0.078 & 0.156 \\
\hline
\end{tabular}

BC: B. cereus DMST 5040, EF: E. faecalis DMST 4736, SA: S. aureus ATCC 25923, SE: S. epidermidis, EC: E. coli ATCC 25922, KP: K. pneumoniae, PA: P. aeruginosa ATCC

27853, PM: P. mirabilis DMST 8212, and ST: S. typhimurium ATCC 13311

\section{Natural hair shampoo formulation}

Based on the previous results, crude ethanolic extracts of VA leaf were the most suitable to apply in our formulation of natural hair shampoo as an auxiliary ingredient based on the grounds of its higher antioxidant $\left(\mathrm{IC}_{50}\right.$ of $\left.1.88 \pm 0.02 \mu \mathrm{g} / \mathrm{ml}\right)$ and antimicrobial activities. In this study, the natural hair shampoo was formulated by the concentration of 10 and 100 times of $\mathrm{IC}_{50}$ value of ethanolic extract shown in Table 1 and named as Formula 1 and Formula 2, respectively. The ethanolic extract of VA leaf was rich in antioxidant and antimicrobial compounds. This valuable point can be used in terms of marketing strategies and the value added of natural shampoo compare with the synthetic active ingredient used shampoo.

\section{Evaluation of natural shampoos}

The physicochemical properties of our formulated natural hair shampoo were evaluated compared with the commercial shampoos, including color, odor, and transparency (Table 6). The formulated shampoo (1) and (2) showed opaque, light yellow-brown in color, and have a pleasant odor (Fig. 1). There was no significant difference ( $p>0.05$ ) between our formulated shampoo and commercial shampoo in terms of odor characteristic by 30 volunteer testing. However, the color and transparency levels were significantly different.

The $\mathrm{pH}$ level of shampoo is correlated to hair damage. Shampoo with neutral $\mathrm{pH}(\mathrm{pH}$ 6.5-6.9) can reduce eye irritation between use, improves hair quality, and maintains the ecological balance of the scalp [38]. The $\mathrm{pH}$ of formulated and commercial shampoos has shown in Table 6. The acid balanced values were observed with commercial shampoos (6.8 \pm 0.02$)$. The $\mathrm{pH}$ of formulated shampoo (1) and (2) was found to be nearly commercial with a pH of $6.7 \pm 0.02$ and $6.5 \pm 0.02$, respectively. High quality shampoo should contain only $20-30 \%$ of solid content $[22,39]$. The high solid content shampoo will be difficult in the washing out process. In this study, both formulated shampoo (1) and (2) showed higher solid content than commercial shampoo as $26.23 \pm$ $0.30 \%$ and $26.45 \pm 0.50 \%$ compared with $25.53 \pm 0.20 \%$. However, the solid content of both shampoos was still lower than $30 \%$. Thus, our formulated shampoos can be considered as easy to rinse shampoo. Another important point of quality shampoo is the dispersion and cleaning performance on the dirty hair. The dispersion of shampoo is an important criterion in shampoo evaluation in terms of cleaning action. If ink or dirt was still appearing inside the shampoo foam, the shampoo
Table 6: Characterizations of formulated and commercial shampoos

\begin{tabular}{llll}
\hline $\begin{array}{l}\text { Evaluation } \\
\text { parameters }\end{array}$ & \multicolumn{2}{l}{ Formulated shampoos } & $\begin{array}{l}\text { Commercial } \\
\text { shampoo } \\
\text { (Naturals Argan) }\end{array}$ \\
\cline { 2 - 4 } & $\mathbf{1}$ & $\mathbf{2}$ & Light \\
\hline Color & Light yellow & Light brown & Pleasant \\
Odor & Pleasant & Pleasant & Transparent \\
Transparency & Opaque & Opaque & $6.80 \pm 0.02$ \\
pH & $6.70 \pm 0.02$ & $6.50 \pm 0.02$ & $25.53 \pm 0.20$ \\
$\%$ Solid content & $22.23 \pm 0.30$ & $22.45 \pm 0.50$ & $114 \pm 5$ \\
Foam volume (ml) & $95 \pm 5$ & $97 \pm 5$ & 155 \\
Wetting time (s) & 157 & 152 & Good \\
Dirt dispersion & Good & Good & \\
\hline
\end{tabular}

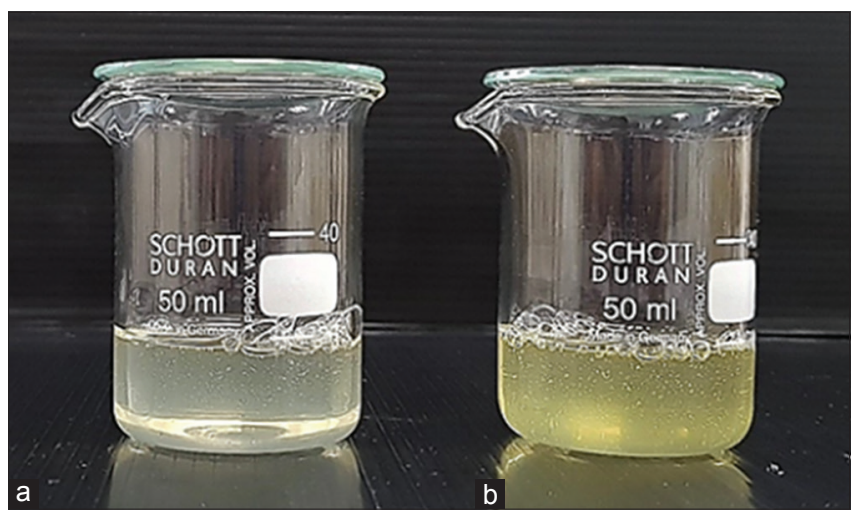

Fig. 1: Physical appearance of formulated natural shampoos $(1 ;$ a) and $(2 ; b)$

will be considered as poor quality shampoo [22]. Our experiment found that both formulated shampoo (1) and (2) can stay over and did not rapidly slip out of the hair. Both formulated shampoo and commercial shampoo showed similar absorption of hair dirt into the foam during the coverage time over the hair. Therefore, both formulated and commercial shampoos were classified as good in the dirt dispersion parameter (Table 6). 
The foam quality and foam stability formulations have been shown in Table 6. Our formulation (1) and (2) showed good foam quality and stability. The remaining time of foam forming was about $5 \mathrm{~min}$. Both formulated shampoo (1) and (2) generated the foam volume of $95 \pm 5$ and $97 \pm 5 \mathrm{ml}$, respectively, while commercial shampoo produced a foam volume of $114 \pm 5 \mathrm{ml}$ (Table 6). The formation of foam of our formulated shampoo showed similar sizes, uniform, denser, and stability compared with the commercial samples. In the wetting time test, the wetting times of our formulated shampoos (1) and (2) were 157 and $152 \mathrm{sec}$, while the commercial shampoo showed the wetting times of $155 \mathrm{~s}$ (Table 6). The good quality shampoo should express high wetting times to demonstrate the diffusion ability. Long wetting time can represent a penetration performance of shampoo to the hair shaft [21].

The product satisfaction testing of formulated shampoo (1) and (2) was evaluated in terms of appearance, odor, color, foaming quantity, feelings after use, packaging, and overall acceptability by 5 -point hedonic scales ( $n=30$ persons). The acceptability scores of formulated shampoo (1) showed a higher score in all terms compared with formulated shampoo (2). The overall acceptability scores of formulated shampoo (1) and (2) were $4.33 \pm 0.55$ (like modulately) and $3.63 \pm 0.49$ (like modulately). In our experiment, the commercial shampoo obtained a customer satisfaction score as $3.57 \pm 0.63$ (like modulately).

\section{CONCLUSIONS}

The crude extracts of VA leaf represent some potential bioactive phytochemical compounds, including saponins, flavonoids, tannins, steroids, terpenoids, cardiac glycosides, and alkaloids which responsible for the antioxidant and antibacterial activities of the plant. These phytochemical compounds exhibited as a broad-spectrum agent in antibacterial activity against both Gram-positive (four tested strains) and Gram-negative (five tested strains) bacteria. The phytochemical in different solvent extraction (distilled water, 95\% ethanol, 75\% acetone, and $99.8 \%$ chloroform) showed different efficiency of bioactive activities (antioxidant and antimicrobial activities) which could be due to their difference in polarity and the ability in phytochemical extraction in the plant samples. The ethanolic and acetonic extracts of VA leaf provided more consistent antimicrobial activity when compared with aqueous and chloroform extracts. Although the ethanolic crude extract expressed lower TPC and TFC than other solvents, it showed the highest antioxidant activity by DPPH assay as $85.730 \pm 0.001$ of inhibition percentage and $\mathrm{IC}_{50}$ value of $1.88 \pm 0.02 \mu \mathrm{g} / \mathrm{ml}$. Thus, the ethanolic crude extract of VA leaf is a rich antioxidant and antimicrobial source and suitable to apply in the natural hair shampoo development. From our experiment, formulation 1 of natural hair shampoo was the most suitable for further commercial development. This formula showed good characteristics, stability, and obtained the highest satisfaction score $(4.33 \pm 0.55)$ (evaluated by 30 volunteers). Therefore, VA is a potential source of natural antioxidant and antimicrobial agents to use in natural cosmetic products. Natural hair shampoo from VA extract was not only clean the hair but also contains bioactive substances that protect the hair from oxidative substances or pathogenic bacteria with low effect to the normal skin bacterial flora (S. epidermidis). This herbal product can help to reduce the skin irritation of users in terms of antioxidant. Thus, further development of this herbal is noticeable in terms of natural product development.

\section{ACKNOWLEDGMENTS}

The author would like to thanks the Faculty of Applied Sciences, King Mongkut's University of Technology North Bangkok (No. 6347101) for financial support and also thanks to the Department of Biotechnology, Faculty of Applied Science, KMUTNB for supplying all of the chemicals and equipment in this research.

\section{AUTHORS' CONTRIBUTIONS}

Sirikhwan Tinrat analyzed the laboratory work, analyzed the data, and wrote the manuscript. Both authors read and approved the manuscript.

\section{CONFLICTS OF INTEREST}

The authors declare that there are no conflicts of interest.

\section{REFERENCES}

1. Yuan H, Ma Q, Ye L, Piao G. The traditional medicine and modern medicine from natural products. Molecules 2016;21:559.

2. Revansiddappa M, Sharadha R, Abbulu K. Formulation and evaluation of herbal antidandruff shampoo. J Pharmacol Phytochem 2018;7:764-7.

3. Adaramoye O, Ogungbenro B, Anyaegbu O, Fafunso M. Protective effects of extracts of Vernonia amygdalina, Hibiscus sabdariffa and Vitamin $\mathrm{C}$ against radiation-induced liver damage in rats. J Radiat Res 2008;49:123-31.

4. Alara OR, Abdurahmana NH, Ukaegbub CI, Kabbashi NA. Extraction and characterization of bioactive compounds in Vernonia amygdalina leaf ethanolic extract comparing Soxhlet and microwave-assisted extraction techniques. J Taibah Univ Sci 2019;13:414-22.

5. Ilondu EM. Antifungal activities of three Vernonia spp. Phytochemical composition and efficacy of ethanolic leaf extracts of some. J Biopestic 2010;6:165-72.

6. Alara OR, Abdurahman NH, Abdul Mudalip SK, Olalere OA. Effect of drying methods on the free radicals scavenging activity of Vernonia amygdalina growing in Malaysia. J King Saud Univ Sci 2017;31:495-99.

7. Onasanwo SA, Oyebanjo OT, Ajayi AM, Olubori MA. Anti-nociceptive and anti-inflammatory potentials of Vernonia amygdalina leaf extract via reductions of leucocyte migration and lipid peroxidation. J Intercult Ethnopharmacol 2017;6:192-8.

8. Jisaka M, Ohigashi H, Takegawa K, Huffman MA, Koshimizu K. Antitumoral and antimicrobial activities of bitter sesquiterpene lactones of Vernonia amygdalina, a possible medicinal plant used by wild chimpanzees. Biosci Biotechnol Biochem 1993;57:833-4.

9. Owoeye O, Yousuf S, Akhtar MN, Qamar K, Dar A, Farombi EO, et al. Another anticancer elemanolide from Vernonia amygdalina Del. Int J Biol Chem Sci 2010;4:226-34.

10. Ngatu NR, Okajima MK, Yokogawa M, Hirota R, Takaishi M, Eitoku M, et al. Anti-allergic effects of Vernonia amygdalina leaf extracts in hapten-induced atopic dermatitis-like disease in mice. Allergol Int 2012;61:597-607.

11. Farombi EO, Owoeye O. Antioxidative and chemopreventive properties of Vernonia amygdalina and garcinia bioflavonoid. Int J Environ Res Public Health 2011;8:2533-55.

12. Luo X, Jiang Y, Fronczek FR, Lin C, Izevbigie EB, Lee S, et al. Isolation and structure determination of a sesquiterpene lactone (vernodalinol) from Vernonia amygdalina extracts. Pharm Biol 2011;49:464-70.

13. Harborne JB. Phytochemical Methods, a Guide to Modern Techniques of Plant Analysis. London: Chapman \& Hall; 1998. p. 182-90.

14. Singleton VL, Orthofer R, Lamuela-Raventós RM. Analysis of total phenols and other oxidation substrates and antioxidants by means of folin-ciocalteu reagent. Meth Enzymol 1999;299:152.

15. Tinrat S, Sila-Asna M. Phytochemical screening and influence of extraction solvents on antioxidant and antimicrobial activities of Asparagus racemosus wild. Root, Int J Phytomed 2017;9:343-51.

16. Jayalakshmia B, Raveeshab KA, Muralic M, Amruthesh KN. Phytochemical, antibacterial and antioxidant studies on leaf extracts of piper betle L. Int J Pharm Pharm Sci 2015;7:23-9.

17. Benzie IF, Strain JJ. The ferric reducing ability of plasma (FRAP) as a measure of antioxidant power: The FRAP assay. Anal Biochem 1996;239:70-6.

18. Bauer AW, Kirby WM, Sherris JC, Turk M. Antibiotic susceptibility testing by a standardized single disk method. Am J Clin Pathol 1996;45:493-6.

19. Kiessoun K, Roland MN, Mamounata D, Yomalan K, Sytar O, Souz A, et al. Antimicrobial profiles, antidiarrheal and antipyretic capacities of phenol acid rich-fractions from Ximenia america L., (Olacaceae) in wistar albino rats. Int J Pharm Pharm Sci 2018;10:62-8.

20. Aghel N, Moghimipour B, Dana RA. Formulation of a herbal shampoo using total saponins of Acanthophyllum squarrosum. Iran J Pharm Res 2007;6:167-72.

21. Manikar AR, Jolly CI. Evaluation of commercial herbal shampoos. Int J Cosmet Sci 2000;22:385-91.

22. Al Badi K, Khan SA. Formulation, evaluation and comparison of the herbal shampoo with the commercial shampoos. Beni Suef Univ J Basic Appl Sci 2014;3:301-5.

23. Cartagena E, Montanaro S, Bardón A. Improvement of the antibacterial activity of sesquiterpene lactones. Rev Latinoam Química 2008;36:43-51.

24. Cowan MM. Plant products as antimicrobial agents. Clin Microbiol 
Rev 1999;12:564-82.

25. Sibanda T, Okoh AI. The challenges of overcoming antibiotic resistance: Plant extracts as potential sources of antimicrobial and resistance modifying agents. Afr J Biotechnol 2007;6:2886-96.

26. Kolawole S, Obueh H, Ukachi A. Antibacterial effect of Vernonia Amygdalina and Ocimum Gratissimum on some Bacteria that cause opportunistic infections in HIV/AIDS patients. J Nutr Health Food Sci 2018;6:1-5.

27. Evbuomwan L, Chukwuka EP, Obazenu EI, Ilevbare L. Antibacterial activity of Vernonia amygdalina leaf extracts against multidrug resistant bacterial isolates. J Appl Sci Environ Manage 2018;22:17-21.

28. Shah SR, Ukaegbu CI, Hamid HA, Alara OR. Evaluation of antioxidant and antibacterial activities of the stems of Flammulina velutipes and Hypsizygus tessellatus (white and brown var. Extracted with different solvents). J Food Meas Charact 2018;12:1947-61.

29. Liguori I, Russo G, Curcio F, Bulli G, Aran L, Della-Morte D, et al. Oxidative stress, aging, and diseases. Clin Interv Aging 2018;13:757-72.

30. Satyal P, Dosoky NS, Poudol A, Setzer WN. Essential oil constituents and their biologic activities from the leaves of Cassia fistula growing in Nepal. J Med Aromat Plants 2012;3:1-4.

31. Moure A, Cruz JM, Franco D, Domínguez JM, Sineiro J, Domínguez H, et al. Natural antioxidants from residual sources. Food Chem 2001;72:145-71.

32. Arekemase MO, Oyeyiola GP, Balogun KI. Assessment of bitter leaf
(Vernonia amygdalina) on some selected pathogenic microorganisms from university of Ilorin teaching hospital. J Microb Biotech Food Sci 2013;2:2360-65.

33. Lyumugabe F, Uyisenga JP, Bayingana C, Songa EB. Antimicrobial activity and phytochemical analysis of Vernonia aemulans, Vernonia amygdalina, Lantana camara and Markhamia lutea leaves as natural beer preservatives. Am J Food Technol 2017;12:35-42.

34. Ogundare AO. Antibacterial properties of the leaf extracts of Vernonia amygdalina, Ocimum gratissmum, Corchorois olitorius and Manihot palmate. J Microbiol Antimicrob 2011;3:77-86.

35. Habtom S, Gebrehiwo S. In vitro antimicrobial activities of crude extracts of Vernonia amygdalina and Croton macrostachyus against some bacterial and fungal test pathogens. J Phytopharmacol 2019;8:57-62.

36. Okigbo RN, Igwe DI. Antimicrobial effects of Piper guineense Uziza and Phyllantus amarus Ebe-benizo on Candida albicans and Streptococcus faecalis. Acta Microbiol Immunol Hung 2008;54:353-66.

37. Ochei J, Kolhatkar A. Isolation and identification Bacteria. In: Medical Laboratory Science Theory and Practice. New York: McGraw-Hill Publishing Company Limited; 2008. p. 644-58.

38. Baran R, Maibah HI. Cosmetic dermatology in children. In: Text Book of Cosmetic Dermatology. London: CRC Press; 1998. p. 507-8.

39. AlQuadeib BT, Eltahir EK, Banafa RA, Al-Hadhairi LA. Pharmaceutical evaluation of different shampoo brands in local Saudi market. Saudi Pharm J 2018;26:98-106. 